\title{
Serum sphingosine-1-phosphate
} levels and Sphingosine-1-Phosphate gene polymorphisms in acute respiratory distres syndrome: a multicenter prospective si $\mathrm{d} d \mathrm{~d} y$

\author{
Jiangnan Zhao ${ }^{1}$, Yan Tan², Li Wang ${ }^{2}$, Xin Su ${ }^{1}$ and Yi Shi ${ }^{{ }^{*}}$ (1)
}

\begin{abstract}
Background: Sphingosine-1-phosphate (S1P) is a signaling phospholi pla olved in pathophysiologic progression of acute respiratory distress syndrome (ARDS) through its roles in endoth - cial barrier function and immune modulation. We hypothesized that decreased serum S1P level is associntod with te clinical outcomes of ARDS and polymorphisms in the S1P gene are associated with serum S1P leve's

Methods: This multicenter prospective study includec $\triangle \mathrm{RD}$, atie its and healthy blood donors as controls. Serum S1P levels were quantified using enzyme-linked imn uno orber assays. Eight tag single nucleotide polymorphisms (SNPS) in the S1P gene were detected, and their zrso tons, ith S1P levels were evaluated.

Results: A total of 121 ARDS patients and 10 , valthy in , viduals were enrolled. Serum S1P levels were lower in ARDS patients than in controls $(P<0.001)$. Ducrea. $\mathrm{d}$ S1P levels correlated with more organ dysfunction and higher Acute Physiology and Chronic Health E aluation II S,ores. Changes in S1P levels in ARDS patients were associated with the clinical outcomes. The recess, e model for SNP rs3743631 suggests that GG homozygote is associate with a higher risk for ARDS. The dominant mod $f_{n}$ sNP rs907045 suggests that AA or TA genotype might increase the risk for ARDS. In ARDS patients, the i 531 GG genotype showed lower S1P levels than those harboring AG and AA genotypes. The serum S1P levels If/590/045 AA or TA genotype patients were lower than those of TT genotype.

Conclusions: Serum S P IE els ar dramatically decreased in ARDS patients. Reduced S1P levels are associated with worse clinical outco mes. "her a significant association between S1P rs3743631, rs907045 polymorphisms and susceptibility of $\mathrm{ADS}$.
\end{abstract}

Keywords: Sowingo ne-1-phosphate (S1P), ARDS, Gene polymorphisms

\section{Backe und}

Ac re nirato y distress syndrome (ARDS) is an acute life-th atenng inflammatory lung injury characterized by severe Aypoxemia and stiff lungs due to diffuse alveolar

\footnotetext{
*Correspondence: yishi201607@163.com

1 Department of Respiratory and Critical Medicine, Jinling Hospital, Medical School of Nanjing University, No. 305 Zhongshan East Road, Nanjing 210000, China

Full list of author information is available at the end of the article
}

injury and immune cell infiltration [1,2]. Although vast improvements have been made in ARDS treatment in the past decade, the mortality rate of patients with severe ARDS remains unacceptable at 45\% [1]. Therefore, early identification of patients at risk is crucial to allow them to benefit from timely treatment. The pathophysiologic causes underlying ARDS include endothelial barrier disruption, dysregulated cytokine secretion, and profound

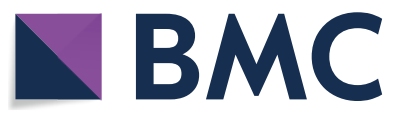

(c) The Author(s) 2020. This article is licensed under a Creative Commons Attribution 4.0 International License, which permits use, sharing, adaptation, distribution and reproduction in any medium or format, as long as you give appropriate credit to the original author(s) and the source, provide a link to the Creative Commons licence, and indicate if changes were made. The images or other third party material in this article are included in the article's Creative Commons licence, unless indicated otherwise in a credit line to the material. If material is not included in the article's Creative Commons licence and your intended use is not permitted by statutory regulation or exceeds the permitted use, you will need to obtain permission directly from the copyright holder. To view a copy of this licence, visit http://creativeco mmons.org/licenses/by/4.0/. The Creative Commons Public Domain Dedication waiver (http://creativecommons.org/publicdomain/ zero/1.0/) applies to the data made available in this article, unless otherwise stated in a credit line to the data. 
lung inflammatory response [3, 4], all of which are potentially regulated by sphingosine-1-phosphate (S1P).

S1P, a biologically active lipid, signals through specific G-protein-coupled receptors (receptors 1-5, S1PR1-5) and elicits multiple physiologic functions, especially in the vascular and immune systems [5-7]. S1P is a potent barrier-enhancing agent and the major endothelial chemotactic factor present in the serum [8,9]. Previous evidence has demonstrated that the circulating S1P level is significantly lower in the presence of sepsis [10] and acute dengue infection [11], in which inflammation and endothelial damage play causal roles. In an acute lung injury (ALI) model, S1P delivery reduced vascular leak and attenuated oxygenation impairment [12]. In animal models of infection-induced micro-vascular endothelial dysfunction, administration of S1P analogues stabilized the micro-vascular endothelium, reduced excessive cytokine production and improved the outcome $[13,14]$. Considering these observations, S1P could be a critical factor for preserving the endothelial barrier integrity and eliciting immunomodulatory effects against the progression of ARDS.

The mechanisms underlying ARDS are compley and may involve a variety of processes influenced by ren factors. S1PR3 gene polymorphism has bee reportea to constitute risk factors for ARDS [15]. Yre thus neculated that the polymorphism of S1P wa, associated with the risk of ARDS. It is unknown whet er diffe ences in serum S1P levels among patients are $\mathrm{cor}$ ated with polymorphisms in the S1P gene. fore, we postulated that (1) serum S1P levels are sub t ntr ly decreased in ARDS patients and could $\mathrm{DC}$ valu ble predictor of disease severity, and (2) get tis ". reflect the serum $\mathrm{S} 1$, levels

\section{Methods}

\section{Patients an con ols}

All participa - or heir surrogate care providers gave writt $n$ forme consent. The protocol was approved by th e ommittee of Jinling Hospital and Nanjing First Ho ital (Approval No.: JLYY: 2013021).

This was a prospective, multicenter, observational cohort study performed in four intensive care units (ICUs) (two respiratory ICUs, one medical ICU, and one emergency ICU) at two tertiary-care, university-affiliated hospitals in Nanjing, China (Jinling Hospital and Nanjing First Hospital). Patients aged $\geq 18$ years who were admitted to one of the four participating ICUs with identified ARDS from January 2018 to August 2019 were considered eligible for inclusion in this study.

All admitted patients with invasive mechanical ventilation (IMV) were screened for eligibility by senior intensive care physicians. ARDS patients were identified by physicians blinded to S1P levels and S1P genotypes, based on the criteria from the Berlin definition [1]. Patients with diffuse alveolar hemorrhage, chropic lung disease other than chronic obstructive pulm nary disease or asthma, directive to withhold intuba ' 1 , an $t$ immunosuppression not secondary to corticos cids, and those treated with granulocyte co ny-stil huating factor were excluded. Patients wer ado ru. to at if they had experienced a cardiac arrest before enrolment, had died or were discharged witt in 4 h of $\mathrm{CU}$ admission, were admitted for uncomplica $d$ overdose, or had been admitted to the ICU for 3 days $\Delta$ 'sre enrollment.

The control cohor co isted of 100 healthy blood donors. Healthy trols $n$ e defined as individuals without any $r$ nt icute illness or any chronic illness requiring evaluat by physicians. The controls were kept anor ous, an only age, gender and ethnicity were collected.

\section{-in. levaluations and assays}

The $\mathrm{p}_{\mathrm{c}}$ ients' demographic and baseline clinical characa isti, s, including age, gender, ethnicity, medical histor and vital signs were recorded at enrollment. Within $4 \mathrm{~h}$ after admission, blood samples were obtained from ARDS patients as soon as possible after confirming that they met the inclusion criteria for S1P measurement, as were baseline levels. The blood samples were also used to determine other clinical parameters. To stratify the distinct time points during the illness, blood samples were collected on day 7 if the patients were alive at this time point. The primary outcome was all-cause in-hospital mortality and the secondary outcome was ventilatorfree days (VFDs). The number of VFDs was defined as the number of days from day 1 to day 28 during which a patient had been breathing without assistance for at least 48 consecutive hours. Patients with $\geq 28$ ventilator days and non-survivors were considered to have 0 VFD.

\section{Serum preparation and S1P measurements}

After coagulation at $4{ }^{\circ} \mathrm{C}$, blood samples were cleared by centrifugation and serum was immediately frozen and stored at $-80{ }^{\circ} \mathrm{C}$ until S1P measurement. The measurements were carried out blindly in duplicates using enzyme-linked immunosorbent assays kits (Echelon Biosciences, Inc., Salt Lake City, UT, USA).

\section{SNPs selection and genotyping}

The Single nucleotide polymorphisms (SNPs) were selected using information from the GenBank and HapMap databases. We selected tag SNPs in the genomic region including the $S 1 P$ gene and 2000 bp upstream and downstream, with the minimum allele frequency set at $5 \%$ and $r^{2}$ at 0.8 . The selected SNPs were located within 
the coding region, $5^{\prime}$ untranslated region (UTR) and $3^{\prime}$ UTR of the S1P gene. A total of eight tag SNPs with representativeness were genotyped.

Genomic DNA was extracted from the whole blood with the QIAamp DNA Blood Mini Kit (Qiagen, Berlin, Germany) using standard procedures. The selected tag SNPs were genotyped using the improved Multiple Ligase Detection Reaction assay technology on an ABI Prism 377 Sequence Detection System (Applied Biosystems, Foster City, CA, USA) with technical support from the Shanghai Genesky Biotechnology Company. To ensure the accuracy of genotyping, negative controls were included in each plate. Genotyping was performed by investigators blinded to clinical status.

\section{Statistical analysis}

Continuous variables were described as median (interquartile range $[\mathrm{IQR}])$. For continuous variables, the Mann-Whitney U test or Kruskal-Wallis analysis were used to compare groups. Categorical variables summarized as proportions were compared using Pearson's Chi square or Fisher's exact test. The relationst ${ }^{\mathrm{r}}$ between two variables was assessed using Pearsor correlation analysis and Spearman rank analysis. pcè $r$ operating characteristic (ROC) curves were structea and the areas under the ROC curves (ANOs) o calculated. Diagnostic AUCs were compared usin the Z-test. The genotypic data of each SN was assessed in terms of Hardy-Weinberg equilibrium 11: g the Chi square goodness-of-fit test. The C. nant model, dominant model anc rece, olve model were used to compare the diff crt ce in renotype distribution between patients and $c_{c}+r$ The strength of association between S1P Olymor 'ism and the risk of ARDS was evaluated $\mathrm{b} / \mathrm{c}$-s ratic (OR) and 95\% confidence interval (CI). stistica ralysis was performed using the SPSS 24.0 ftw re and the GraphPad Prism 7 software. $\mathrm{P}<0.05$ was $\mathrm{s}$ side ed statistically significant.

\section{Resu.}

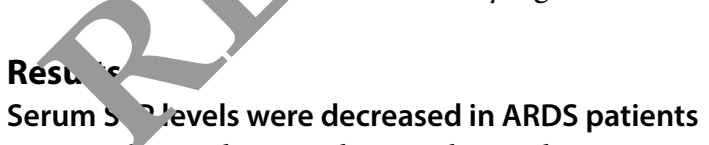

During the study period, 332 admitted patients with IMV were screened. According to the inclusion and exclusion criteria, 121 ARDS patients were enrolled for analysis. The detailed demographic and clinical characteristics of the study patients are provided in Table 1.

Serum S1P levels were measured in 121 ARDS patients and 100 healthy controls. Both groups showed a male predominance; however, the age and gender distribution did not differ between the groups (Table 2). Patients with ARDS had significantly lower serum S1P levels (median $303.0 \mathrm{nmol} / \mathrm{L}$, IQR 221.3-418.5 $\mathrm{nmol} / \mathrm{L}$ ) than controls (median $930.5 \mathrm{nmol} / \mathrm{L}$, IQR 733.2-1153.4 nmol/L,
Table 1 Demographic and clinical characteristics of ARDS patients

\begin{tabular}{|c|c|}
\hline Characteristic & Value $(n=121)$ \\
\hline \multicolumn{2}{|l|}{ Age, years } \\
\hline \multicolumn{2}{|l|}{ Male sex } \\
\hline \multicolumn{2}{|l|}{ Current smokers } \\
\hline \multicolumn{2}{|l|}{ ARDS risk factor } \\
\hline \multicolumn{2}{|l|}{ Sepsis } \\
\hline Pneumonia & $22(18.2)$ \\
\hline Aspiration & $12(11.6)$ \\
\hline Acute pancreatitis & $16(15.7)$ \\
\hline Vasopressors use at & $36(29.8)$ \\
\hline \multicolumn{2}{|c|}{ Coexisting conditions } \\
\hline Hypertension & $33(27.3)$ \\
\hline Diabetes & $16(13.2)$ \\
\hline onary & $11(9.1)$ \\
\hline בע & $15(12.4)$ \\
\hline Chronic rena & $20(16.5)$ \\
\hline or asthr 4 & $11(9.1)$ \\
\hline & $11(9.1)$ \\
\hline \multicolumn{2}{|c|}{ borat y values on diagnosis of ARDS } \\
\hline by count, $\times 10^{9} / \mathrm{L}$ & $12.7(10.14-17.5)$ \\
\hline Hematocrit, \% & $28.0(23.5-34.1)$ \\
\hline Platelet count, $\times 10^{9} / \mathrm{L}$ & $174(92.5-259)$ \\
\hline Serum bilirubin, $\mu \mathrm{mol} / \mathrm{L}$ & $26.3(12.5-49.8)$ \\
\hline Serum creatinine, $\mu \mathrm{mol} / \mathrm{L}$ & $120.6(69.5-173.9)$ \\
\hline Serum albumin, $g / L$ & $29.4(27.3-31.95)$ \\
\hline APACHE II score & $25(21-29)$ \\
\hline No. of organ failures & $2(0-3)$ \\
\hline Lowest $\mathrm{PaO}_{2} / \mathrm{FiO}_{2}$ ratio & $170.4(124.0-257.0)$ \\
\hline \multicolumn{2}{|l|}{ Berlin categories } \\
\hline Mild & $44(36.4)$ \\
\hline Moderate & $56(46.3)$ \\
\hline Severe & $21(17.4)$ \\
\hline Days in ICU & $16.0(10.0-29.5)$ \\
\hline Ventilator-free days & $12.0(7.0-21.0)$ \\
\hline Death in hospital & $33(27.3)$ \\
\hline
\end{tabular}

Continuous variables are presented as median (interquartile range); categorical variables are presented as No.(\%)

ARDS Acute respiratory distress syndrome, WBC white blood cell, APACHE II Acute Physiology and Chronic Health Evaluation II, No. of organ failures includes only non-pulmonary organ failures; ICU intensive care unit

$\mathrm{P}<0.001$ ) (Fig. 1a). Gender bias was not detected in both controls and patients (Fig. 1b). ARDS patients also had significantly lower red blood cells (RBC) count, platelet count, albumin level, and high-density lipoprotein (HDL) level (Table 2).

ARDS patients were then divided into three groups (mild, moderate, and severe) according to decreasing $\mathrm{PaO}_{2} / \mathrm{FiO}_{2}$ ratio. However, the S1P levels did not correlate with worsening Berlin oxygenation categories 
Table 2 Characteristics of study groups

\begin{tabular}{llrl}
\hline Variables & Control $(\mathbf{n}=\mathbf{1 0 0})$ & ARDS $(\mathbf{n}=\mathbf{1 2 1})$ & P value \\
\hline Age, years & $51.0(39.75-65.75)$ & $61.0(43.5-69.0)$ & n.s. \\
Male/Female & $66 / 34(66.0 / 34.0)$ & $84 / 37(69.4 / 30.6)$ & n.s. \\
Ethnicity & & & n.s. \\
$\quad$ Hans & $100(100)$ & $121(100)$ & \\
Serum-S1P, nmol/L & $930.5(733.2-1153.4)$ & $303.0(221.3-418.5)$ & $<0.001$ \\
RBC count, $\times 10^{12} / \mathrm{L}$ & $4.5(3.89-5.063)$ & $2.8(2.475-3.1)$ & $<0.001$ \\
Platelet & $199.5(150.3-253.8)$ & $174(92.5-259)$ & 0.025 \\
$\quad$ count, $\times 10^{9} / \mathrm{L}$ & & & \\
Serum albumin, g/L & $40(36-44.28)$ & $29.4(27.3-31.95)$ & $<0.001$ \\
HDL, $\mathrm{mmol} / \mathrm{L}$ & $1.40(1.04-2.13)$ & $0.57(0.36-0.89)$ & $<0.001$ \\
\hline
\end{tabular}

Continuous variables are presented as median (interquartile range); categorical variables are presented as No. (\%)

ARDS Acute respiratory distress syndrome, n.s. non-significant, S1P sphingosine1-phosphate, $R B C$ red blood cell, HDL high-density lipoprotein

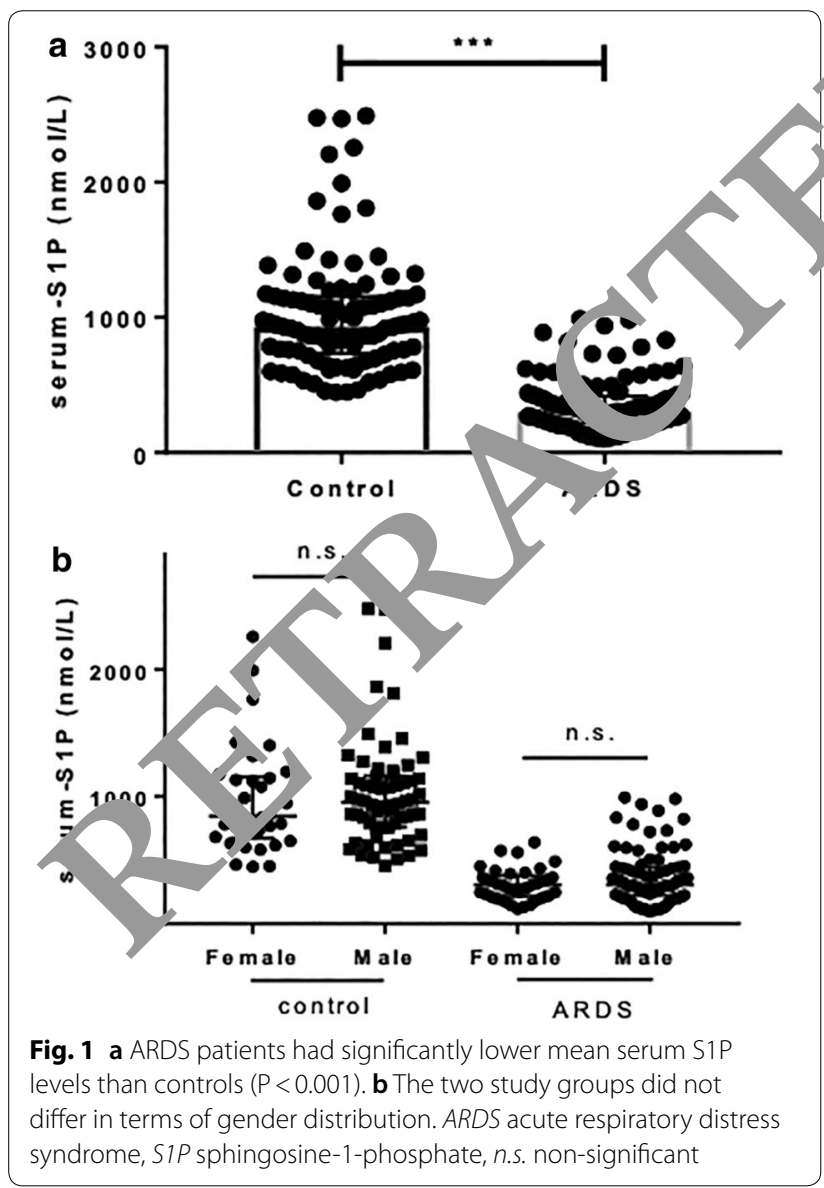

$(\mathrm{P}=0.135)$ (Fig. 2a). The baseline levels of S1P differed with the underlying risk factor for the development of ARDS. Specifically, patients with sepsis as the primary cause of ARDS had lower S1P levels (Fig. 2b).

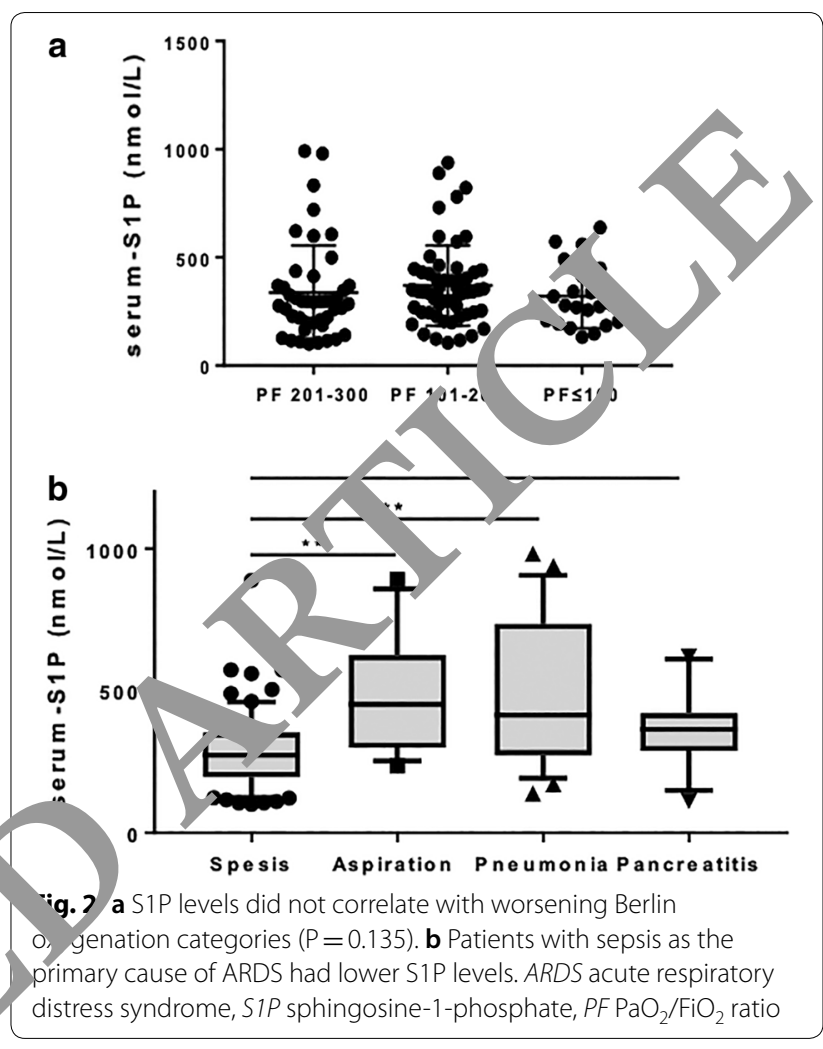

S1P Levels were associated with disease severity

We, subsequently, analyzed the potential correlation between serum S1P levels and organ failures and Acute Physiology and Chronic Health Evaluation II (APACHE II) scores in ARDS patients. Interestingly, Spearman correlation analysis showed that the number of organ failures was negatively correlated with the baseline S1P levels $(r=-0.2477, P=0.006)$. Decreasing S1P levels correlated with increasing number of organ failures (Fig. 3a). The APACHE II score was determined to evaluate the disease severity in the ICU $[16,17]$. We also observed that the baseline serum S1P levels in ARDS patients demonstrated a high and significantly negative linear correlation with the APACHE II scores $(r=-0.286, P=0.002)$, whereas the S1P levels on day 7 showed a weaker, albeit significant, negative linear correlation with disease severity $(\mathrm{r}=-0.219, \mathrm{P}=0.034)$ (Figs. 3b, $\mathrm{c}$ ).

\section{Decreased serum S1P levels may reflect disease outcomes}

To investigate whether changes in S1P levels in ARDS patients were associated with disease progression and outcome, we analyzed S1P levels in 94 patients for whom both baseline and day 7 serum S1P levels were available. These 94 ARDS patients were divided into three groups according to disease outcomes: patients who were discharged from the hospital within 28 days, patients who 
a
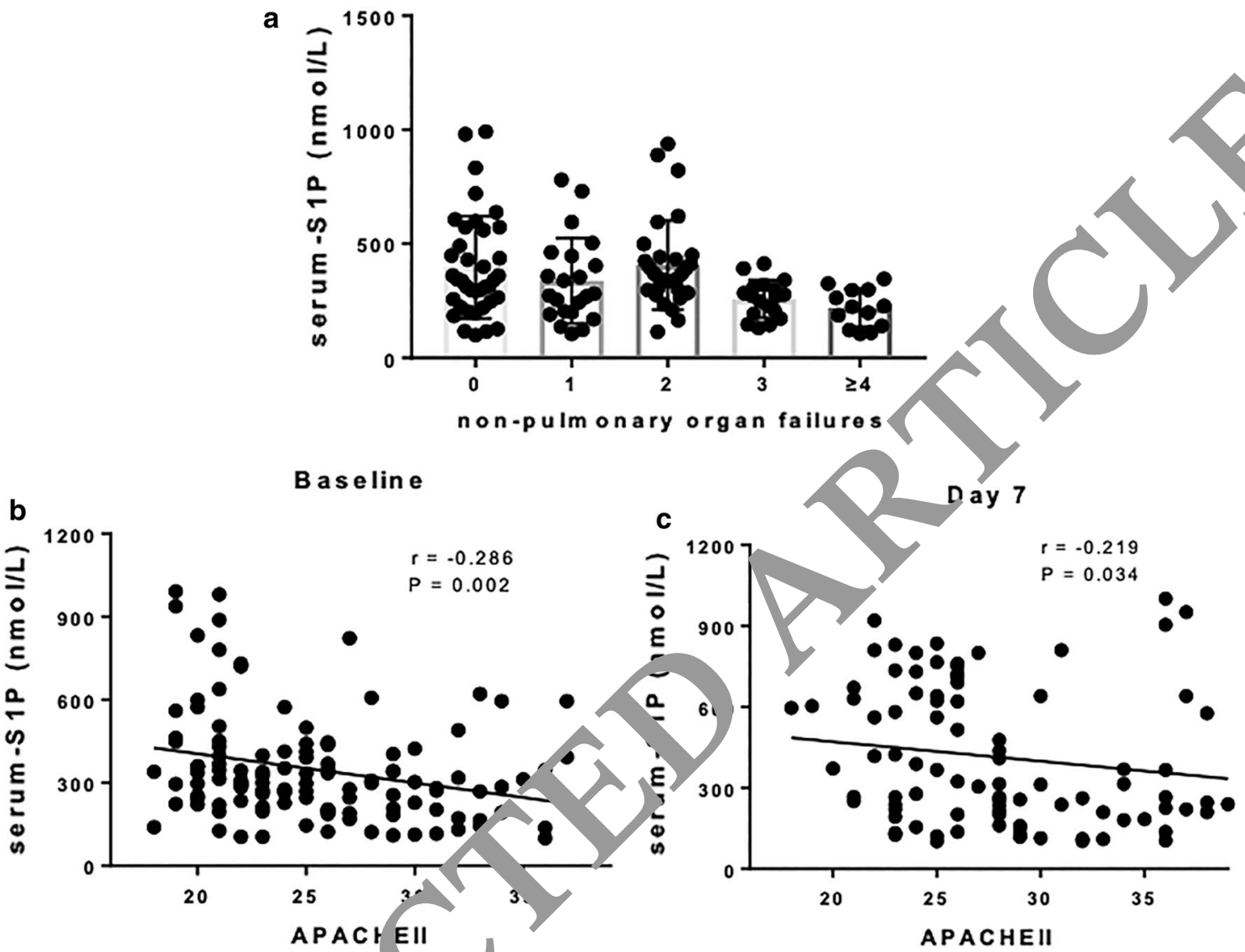

Fig. 3 a S1P levels were associated with the nun of $n$-pulmonary organ failures $(P=0.001)$. b APACHE II scores were highly negatively

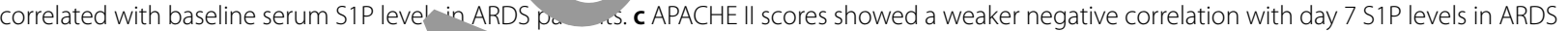
patients. ARDS acute respiratory distress S Ina SIP sphingosine-1-phosphate, APACHE II acute physiology and chronic health evaluation II

were discharged from e than 28 days, and pati nts wh died. Intriguingly, in the group of patien s a harged from the hospital within 28 days, the surum 5 / levels on day 7 significantly increased mp ted with the levels on day $1(\mathrm{P}=0.008)$ (Fig. 4a). Hov ver, $\mathrm{A}$ the groups of patients hospitalized for $z$ IOn er per $a$ or those who died, serum S1P levels rema a during the early stage of illness.

We fu. her analyzed whether S1P levels were related to fatal outcomes. The baseline serum S1P levels were lower in non-survivors (median $224.6 \mathrm{nmol} / \mathrm{L}$, IQR 165.6$331.5 \mathrm{nmol} / \mathrm{L}$ ) than in survivors (median $337.7 \mathrm{nmol} / \mathrm{L}$, IQR 258.1-445.2 nmol/L, $\mathrm{P}<0.001$ ) (Fig. 4b). To evaluate the potential of S1P level for predicting mortality in ARDS patients, a ROC curve analysis was performed. S1P level had moderately good ability to indicate mortality with an identical AUC of 0.70 (95\% CI 0.59-0.80, $\mathrm{P}=0.001)$. On analysis of ROC, the AUCs for APACHE II score was 0.73 and PF ratio was 0.55 , whereas the combination of S1P either with APACHE II score and PF ratio yielded the AUCs of 0.80 and 0.77 , respectively (Fig. 5).
Association between S1P genetic variants and risk of ARDS We analyzed the genotype and allele distribution of SNPs in the ARDS and control groups (Table 3). The genotype frequencies of the studied polymorphisms in control individuals were in Hardy-Weinberg equilibrium. The minor allele frequencies of all of the SNPs in this group were $>5 \%$.

Genotypic differences in rs3743631 between the case and control groups were statistically significant $(\mathrm{P}=0.038)$. Calculation for odds ratios in accordance with a recessive model for rs3743631 suggests that individuals who were homozygous for GG homozygote had a higher risk for ARDS. The subjects of GG genotype were 3.657 times higher risk than those with AA and AG (Recessive model, $\mathrm{OR}=3.657,95 \% \mathrm{CI}=1.181-11.32$, $P=0.024)$. The allele model for SNP rs3743631 suggests that $\mathrm{G}$ allele might increase the risk for ARDS compared to A allele.

We also found that individuals with AA or TA genotype of rs 907045 had higher risk of ARDS compared with those with TT genotype (Additive model). The subjects 

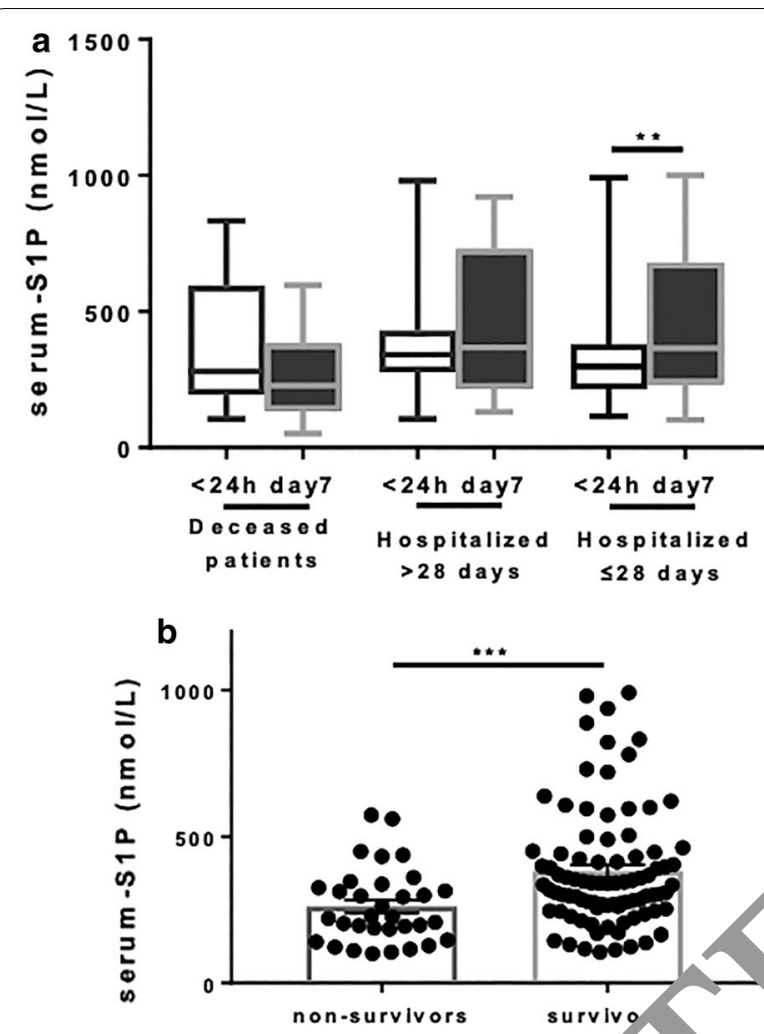

Fig. 4 a Baseline and day 7 S1P serum levels in ARDS $p$ tien, ho died $(n=18)$, in those who were hospitalized for $>20$ anys $(n=2$ and in those who were hospitalized for $\leq 28$ day $(n=49)$. b S1P levels were lower in non-survivors than in surviv $(P<0.001)$. ARDS acute respiratory distress syndrome, SIP sphingosin osphate of AA and TA genotype had 1.885 times higher risk of getting ARDS when compared with the subjects of TT (Dominant model, OR $=1.885,95 \% \mathrm{CI}=1.031-3.446$, $\mathrm{P}=0.039$ ). The A allele of rs 907045 was sifirantly associated with increased risk of ARDS compa, 'with T allele $(\mathrm{P}=0.032)$.

For SNP rs11607, a statistical differ ce wôs found between ARDS group and contri group allele frequency of $\mathrm{T}$ and $\mathrm{C}(\mathrm{P}=0.046)$. To differences in genotypic or allelic frequencies ere bser ed for other 5 SNPs.

\section{Association of gene p lym , hisms with S1P levels}

Serum S1P level contror Mdividuals with rs3743631 GG genotype AA $\perp$ AG genotype did not differ from each other (Fig. T. The S1P levels between rs907045 AA or T notype and TT genotype in control group also showid 10 ignificant differences (Fig. 6b). However, ARDS patients with rs3743631 GG genotype (vs An d AG genotypes) showed lower S1P levels (median $222.7 \mathrm{nmol} / \mathrm{L}, \mathrm{IQR} 126.69-318.61 \mathrm{nmol} / \mathrm{L}$ vs median $4.8 \mathrm{nmol} / \mathrm{L}$, IQR $240.10-436.90 \mathrm{nmol} / \mathrm{L} ; \mathrm{P}=0.004)$. Sin 1 lar results were obtained in the patients with s907045 AA or TA genotype (AA and TA vs TT, median $281.31 \mathrm{nmol} / \mathrm{L}$, IQR $201.69-342.93 \mathrm{nmol} / \mathrm{L}$; vs median $335.73 \mathrm{nmol} / \mathrm{L}$, IQR $235.20-450.46 \mathrm{nmol} / \mathrm{L} ; \mathrm{P}=0.035)$.

\section{Discussion}

This is the first multi-center study to assess the role of S1P in ARDS patients. Detailed clinical data were prospectively collected, and multiple correlations were made with S1P. The major findings of this study were
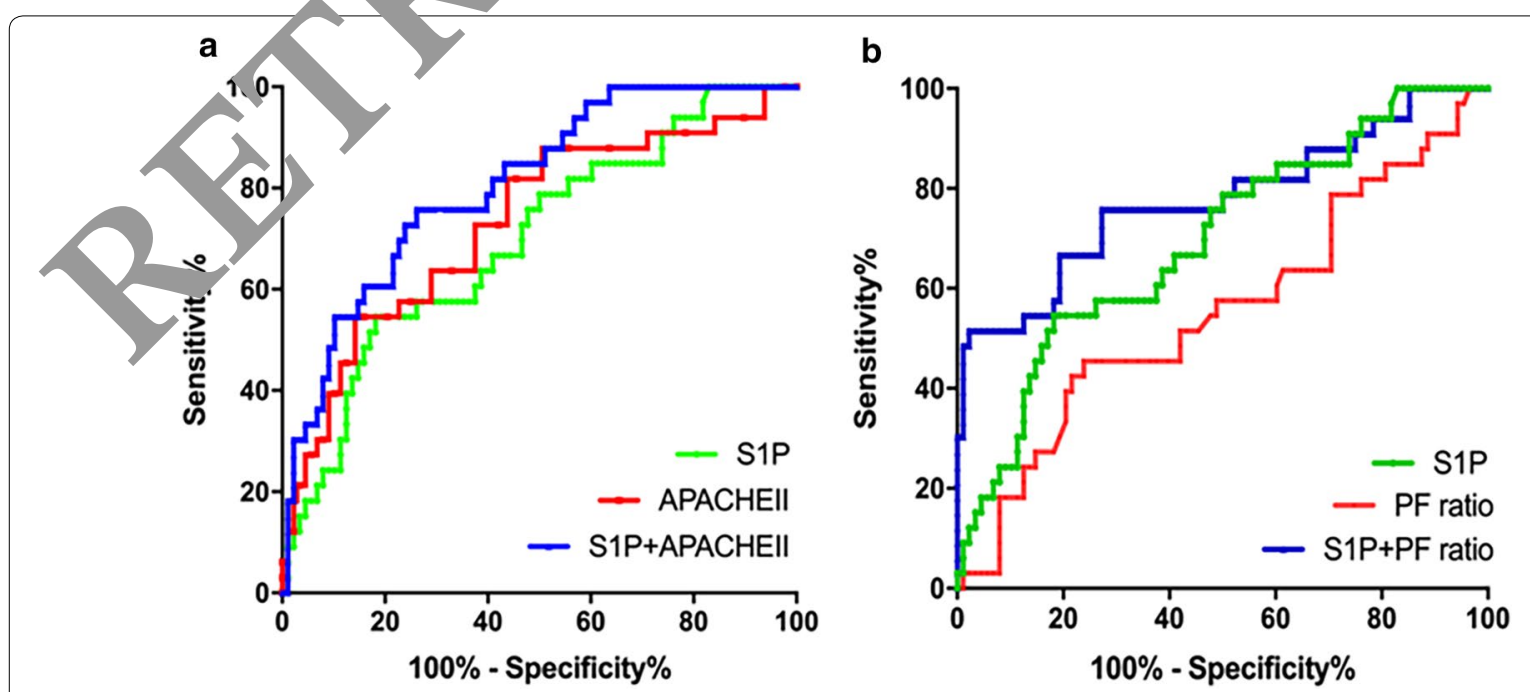

Fig. 5 The ROC curve depicted an improvement in the discriminatory ability of the severity categories based on the APACHE II score (a) and PF ratio (b) with the addition of S1P level to the model. The AUC increased from 0.73 to $0.80(P>0.05)$ and 0.55 to $0.77(P<0.01)$, respectively. ROC receiver operating characteristic, APACHE II Acute Physiology and Chronic Health Evaluation II, PF $\mathrm{PaO}_{2} / \mathrm{FiO}_{2}$, SIP sphingosine-1-phosphate, AUC areas under the curve 
Table 3 Genotype distribution and allele frequency of the tested SNPs in patients and controls

\begin{tabular}{|c|c|c|c|c|c|c|}
\hline SNP & Model & Genotype & Case & Control & OR $(95 \% \mathrm{Cl})$ & va re \\
\hline \multirow[t]{12}{*}{ rs1049884 } & Additive & $\mathrm{T} / \mathrm{T}$ & 2 & 1 & $1.173(0.684-2.009)$ & 19 \\
\hline & & $\mathrm{A} / \mathrm{T}$ & 37 & 28 & & \\
\hline & & $\mathrm{A} / \mathrm{A}$ & 82 & 71 & & \\
\hline & Codominant & $\mathrm{T} / \mathrm{T}$ & 2 & 1 & $1.732(0.153 \cdot 19.5)$ & 0.6567 \\
\hline & & $\mathrm{A} / \mathrm{T}$ & 37 & 28 & 53) & 0.6517 \\
\hline & & $A / A$ & 82 & 71 & & - \\
\hline & Dominant & $\mathrm{T} / \mathrm{T}, \mathrm{A} / \mathrm{T}$ & 39 & 29 & & 0.6045 \\
\hline & & $\mathrm{A} / \mathrm{A}$ & 82 & 71 & & \\
\hline & Recessive & $\mathrm{T} / \mathrm{T}$ & 2 & 1 & 487-18.62) & 0.6795 \\
\hline & & $\mathrm{A} / \mathrm{A}, \mathrm{A} / \mathrm{T}$ & 119 & 99 & & \\
\hline & Allele & $\mathrm{T}$ & 41 & 30 & $0.6918-1.931)$ & 0.5801 \\
\hline & & A & 201 & 170 & & \\
\hline \multirow[t]{12}{*}{ rs11550470 } & Additive & $\mathrm{T} / \mathrm{T}$ & 1 & & $1.499(0.713-3.151)$ & 0.2857 \\
\hline & & $\mathrm{C} / \mathrm{T}$ & 19 & & & \\
\hline & & $\mathrm{C} / \mathrm{C}$ & 101 & 8 & & \\
\hline & Codominant & $\mathrm{T} / \mathrm{T}$ & & 0 & $\mathrm{NA}(\mathrm{NA}-\mathrm{NA})$ & NA \\
\hline & & $\mathrm{C} / \mathrm{T}$ & & 12 & $\mathrm{NA}(\mathrm{NA}-\mathrm{NA})$ & NA \\
\hline & & $\mathrm{C} / \mathrm{C}$ & & 88 & - & - \\
\hline & Dominant & $\mathrm{T} / \mathrm{T}, \mathrm{C} / \mathrm{T}$ & & 12 & $1.452(0.6719-3.138)$ & 0.3427 \\
\hline & & $\mathrm{C} / \mathrm{C}$ & & 88 & & \\
\hline & Recessive & $\mathrm{T} / \mathrm{T}$ & & 0 & $\mathrm{NA}(\mathrm{NA}-\mathrm{NA})$ & NA \\
\hline & & & 120 & 100 & & \\
\hline & Allele & & 21 & 12 & $1.489(0.7135-3.106)$ & 0.289 \\
\hline & & & 221 & 188 & & \\
\hline \multirow[t]{24}{*}{ rs11607 } & Additive & & 17 & 23 & $0.7049(0.4887-1.017)$ & 0.06143 \\
\hline & & & 50 & 42 & & \\
\hline & & & 54 & 35 & & \\
\hline & & $\mathrm{T} / \mathrm{T}$ & 17 & 23 & $0.4791(0.2246-1.022)$ & 0.05691 \\
\hline & & $\mathrm{C} / \mathrm{T}$ & 50 & 42 & $0.7716(0.4273-1.393)$ & 0.3898 \\
\hline & & $\mathrm{C} / \mathrm{C}$ & 54 & 35 & - & - \\
\hline & & $\mathrm{T} / \mathrm{T}, \mathrm{C} / \mathrm{T}$ & 67 & 65 & $0.6681(0.3873-1.153)$ & 0.1471 \\
\hline & & $\mathrm{C} / \mathrm{C}$ & 54 & 35 & & \\
\hline & & $\mathrm{T} / \mathrm{T}$ & 17 & 23 & $0.5472(0.2737-1.094)$ & 0.08804 \\
\hline & & $\mathrm{C} / \mathrm{C}, \mathrm{C} / \mathrm{T}$ & 104 & 77 & & \\
\hline & ele & $\mathrm{T}$ & 84 & 88 & $0.6766(0.4606-0.9941)$ & 0.04658 \\
\hline & & C & 158 & 112 & & \\
\hline & Additive & $A / A$ & 2 & 1 & $1.875(0.8935-3.934)$ & 0.09646 \\
\hline & & $\mathrm{G} / \mathrm{A}$ & 19 & 8 & & \\
\hline & & $\mathrm{G} / \mathrm{G}$ & 100 & 91 & & \\
\hline & Codominant & $A / A$ & 2 & 1 & $1.82(0.1623-20.41)$ & 0.6273 \\
\hline & & $\mathrm{G} / \mathrm{A}$ & 19 & 8 & $2.161(0.9023-5.177)$ & 0.08376 \\
\hline & & $\mathrm{G} / \mathrm{G}$ & 100 & 91 & - & - \\
\hline & Dominant & $\mathrm{A} / \mathrm{A}, \mathrm{G} / \mathrm{A}$ & 21 & 9 & $2.123(0.9251-4.874)$ & 0.0757 \\
\hline & & $\mathrm{G} / \mathrm{G}$ & 100 & 91 & & \\
\hline & Recessive & $A / A$ & 2 & 1 & $1.664(0.1487-18.62)$ & 0.6795 \\
\hline & & $\mathrm{G} / \mathrm{G}, \mathrm{G} / \mathrm{A}$ & 119 & 99 & & \\
\hline & Allele & $A$ & 23 & 10 & $1.995(0.9263-4.299)$ & 0.07766 \\
\hline & & G & 219 & 190 & & \\
\hline
\end{tabular}


Table 3 (continued)

\begin{tabular}{|c|c|c|c|c|c|c|}
\hline SNP & Model & Genotype & Case & Control & OR $(95 \% \mathrm{Cl})$ & $P$ value \\
\hline \multirow[t]{12}{*}{ rs2280026 } & \multirow[t]{3}{*}{ Additive } & $\mathrm{C} / \mathrm{C}$ & 14 & 7 & $1.044(0.6981-1.56)$ & \\
\hline & & $\mathrm{T} / \mathrm{C}$ & 42 & 42 & & \\
\hline & & $\mathrm{T} / \mathrm{T}$ & 65 & 51 & & \\
\hline & \multirow[t]{3}{*}{ Codominant } & $\mathrm{C} / \mathrm{C}$ & 14 & 7 & & 0.3668 \\
\hline & & $\mathrm{T} / \mathrm{C}$ & 42 & 42 & $44(-1.378)$ & 0.3987 \\
\hline & & $\mathrm{T} / \mathrm{T}$ & 65 & 51 & 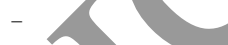 & - \\
\hline & \multirow[t]{2}{*}{ Dominant } & $\mathrm{C} / \mathrm{C}, \mathrm{T} / \mathrm{C}$ & 56 & 49 & & 0.6871 \\
\hline & & $\mathrm{T} / \mathrm{T}$ & 65 & 51 & & \\
\hline & \multirow[t]{2}{*}{ Recessive } & $C / C$ & 14 & 7 & & 0.2534 \\
\hline & & $\mathrm{T} / \mathrm{T}, \mathrm{T} / \mathrm{C}$ & 107 & 93 & & \\
\hline & \multirow[t]{2}{*}{ Allele } & C & 70 & 56 & $1.047(0.6908-1.585)$ & 0.8301 \\
\hline & & $T$ & 172 & & & \\
\hline \multirow[t]{12}{*}{ rs3743631 } & \multirow[t]{3}{*}{ Additive } & $\mathrm{G} / \mathrm{G}$ & 16 & & $1.638(1.069-2.509)$ & 0.02341 \\
\hline & & $A / G$ & 55 & 44 & & \\
\hline & & $A / A$ & & $52^{\prime \prime}$ & & \\
\hline & \multirow[t]{3}{*}{ Codominant } & $\mathrm{G} / \mathrm{G}$ & & 4 & $4.16(1.301-13.3)$ & 0.01623 \\
\hline & & $A / G$ & & 44 & $1.3(0.7464-2.264)$ & 0.354 \\
\hline & & A/A & & 52 & - & - \\
\hline & \multirow[t]{2}{*}{ Dominant } & $\mathrm{G} / \mathrm{G}, \mathrm{A} / \mathrm{G}$ & & 48 & $1.538(0.9021-2.623)$ & 0.1137 \\
\hline & & $\mathrm{A} / \mathrm{A}$ & & 52 & & \\
\hline & \multirow[t]{2}{*}{ Recessive } & & 16 & 4 & $3.657(1.181-11.32)$ & 0.02452 \\
\hline & & & 105 & 96 & & \\
\hline & \multirow[t]{2}{*}{ Allele } & & 87 & 52 & $1.598(1.059-2.409)$ & 0.02542 \\
\hline & & & 155 & 148 & & \\
\hline \multirow[t]{24}{*}{ rs907045 } & \multirow[t]{12}{*}{ Additive } & & 4 & 1 & $1.831(1.055-3.177)$ & 0.03147 \\
\hline & & & 38 & 21 & & \\
\hline & & $1 / 1$ & 79 & 78 & & \\
\hline & & $\mathrm{A} / \mathrm{A}$ & 4 & 1 & $3.949(0.4317-36.13)$ & 0.2239 \\
\hline & & T/A & 38 & 21 & $1.787(0.963-3.314)$ & 0.06569 \\
\hline & & $\mathrm{T} / \mathrm{T}$ & 79 & 78 & - & - \\
\hline & & $\mathrm{A} / \mathrm{A}, \mathrm{T} / \mathrm{A}$ & 42 & 22 & $1.885(1.031-3.446)$ & 0.03945 \\
\hline & & $\mathrm{T} / \mathrm{T}$ & 79 & 78 & & \\
\hline & & A/A & 4 & 1 & $3.385(0.3722-30.78)$ & 0.279 \\
\hline & & $\mathrm{T} / \mathrm{T}, \mathrm{T} / \mathrm{A}$ & 117 & 99 & & \\
\hline & & A & 46 & 23 & $1.806(1.052-3.1)$ & 0.03196 \\
\hline & & T & 196 & 177 & & \\
\hline & \multirow[t]{3}{*}{ Additive } & $\mathrm{A} / \mathrm{A}$ & 6 & 6 & $1.099(0.6956-1.738)$ & 0.685 \\
\hline & & T/A & 33 & 22 & & \\
\hline & & $T / T$ & 82 & 72 & & \\
\hline & \multirow[t]{3}{*}{ Codominant } & A/A & 6 & 6 & $0.878(0.2712-2.843)$ & 0.8283 \\
\hline & & T/A & 33 & 22 & $1.317(0.7046-2.462)$ & 0.3881 \\
\hline & & $T / T$ & 82 & 72 & - & - \\
\hline & \multirow[t]{2}{*}{ Dominant } & $\mathrm{A} / \mathrm{A}, \mathrm{T} / \mathrm{A}$ & 39 & 28 & $1.223(0.6851-2.183)$ & 0.496 \\
\hline & & $T / T$ & 82 & 72 & & \\
\hline & \multirow[t]{2}{*}{ Recessive } & $\mathrm{A} / \mathrm{A}$ & 6 & 6 & $0.8174(0.2552-2.618)$ & 0.7342 \\
\hline & & $\mathrm{T} / \mathrm{T}, \mathrm{T} / \mathrm{A}$ & 115 & 94 & & \\
\hline & \multirow[t]{2}{*}{ Allele } & A & 45 & 34 & $1.115(0.6826-1.822)$ & 0.6632 \\
\hline & & $\mathrm{T}$ & 197 & 166 & & \\
\hline
\end{tabular}



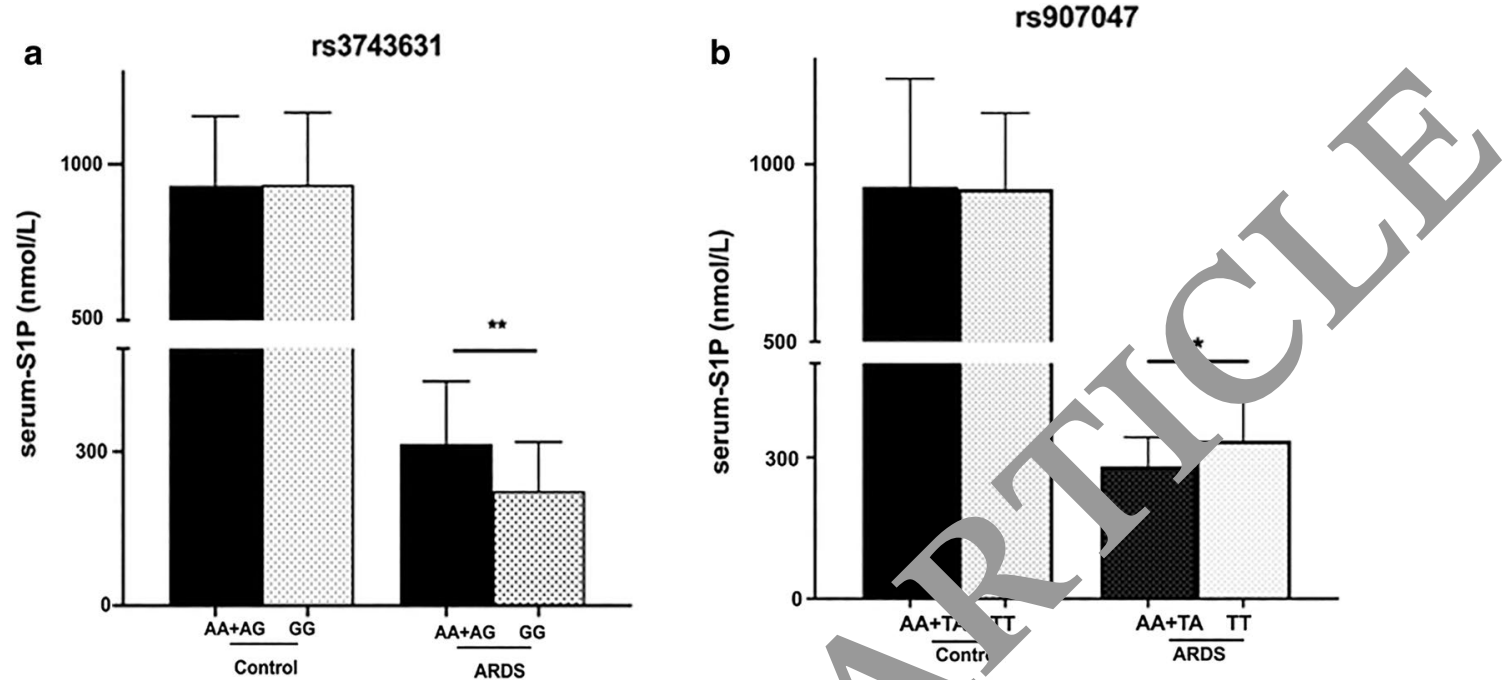

Fig. 6 Serum S1P levels with different genotypes. a The S1P levels of ARDS patients with I 37430, GG genotype were lower than those with AG + AA genotypes. $\mathbf{b}$ The S1P levels of ARDS patients with rs 907045 AA + TA genotypes w re lower than those with TT genotype. No difference was observed in controls. ARDS acute respiratory distress syndrome, SIP sph:

as follows: (1) serum S1P levels were significantlv lo $r$ in ARDS patients than in healthy controls; ( $\mathrm{reduce}$ serum S1P levels in ARDS patients wer as ciated with more organ dysfunction and high 1 mortalit and (3) the S1P rs3743631, rs907045 pr ymorphisms are associated with susceptibility to ARDS

The serum S1P levels in our $h^{1+h y}$ controls are consistent with those reported in tw $r a$ jus studies [10, 11]. Considering that blo samp es from patients and controls were handled th sam way and there is no age dependency an den $r$ bias in the S1P levels, we believe that the 1 , rences 1 . serum S1P levels between controls and patien, were due to ARDS. Platelets, RBCs and end thelial/cells have been proven to be the main su ces f S1P [18-20]. Thrombocytopenia and $\pi$ ia in 1 LDS patients are probably related to th $w$ n 1 . levels in these patients. Endothelial da. ge and barrier disruption play critical roles in ARDS $[3,4]$, which may cause decreased S1P production. Serum S1P levels are also dependent on the level of S1P carrier proteins. In the blood, S1P is predominantly associated with HDL-associated apolipoprotein $M$ (apo M) and to a lesser extent with albumin [21, 22]. In ARDS, both HDL and albumin levels are decreased. Taken together, decreased S1P production, loss of S1P sources and reduced carrier proteins all contribute to lower S1P levels in ARDS patients.

Our study results demonstrate the prognostic value of serum S1P levels measured in the early course of ARDS. $\mathrm{S} 1 \mathrm{P}$, recognized as a potent endothelial cell agonist and ngiogenic factor, directly contributes to the maintenance of the integrity of the vascular endothelium [23, 24]. Intravenous application of S1P to lung-injured animals was found to attenuate lung vascular dysfunction and to increase the endothelial barrier integrity [12, 25]. Mice with decreased circulating S1P levels showed increased vascular permeability, lung edema formation and decreased survival after inflammatory challenge [26]. In addition to maintaining the endothelial integrity, S1P seems to directly modulate the immune response. S1P can prevent neutrophil chemotaxis and the transmigration of neutrophils across an endothelial cell monolayer [27]. In ALI animal models, administration of S1PR agonists inhibited early pro-inflammatory cytokine production, inhibited innate immune cell recruitment and attenuated inflammatory lung injury [14, 28-31].

Serum S1P levels could stratify disease severity and predict the disease outcome in ARDS patients. We are not suggesting the use of S1P as a sole marker in risk stratification or for making decisions about treatment futility. Rather, we want to emphasize the association of S1P levels with mortality owing to its potential utility in combination with other biomarkers and clinical predictors. In our study, S1P levels correlated with the number of non-pulmonary organ failures, but they were not associated with ARDS severity according to the Berlin classification. Partially due to the limited sample size, it is possible that the relationship between S1P and mortality is mediated by multiple organ failure rather than by the severity of lung injury, measured according to 
oxygenation impairment. There is therefore a need to increase the sample size of ARDS patients to verify these results in future investigations.

S1P gene polymorphism in ARDS patients has never been examined. To gain insight into the role of S1P in clinic, we examined S1P gene polymorphism in the blood sample of ARDS patients. In this study, we tested eight candidate SNPs. The genotype and allele frequency of rs3743631, rs907045 and allele frequency of rs11607 had significant differences between ARDS and control. The frequency of the rs3743631 GG homozygote was significantly higher in ARDS patients compared with healthy controls, which indicates that individuals with GG genotype is susceptible to ARDS. The dominant model for SNP rs907045 suggests that AA or TA genotype might increase the risk for ARDS. Another finding indicates that the rs3743631 GG genotype is associated with lower plasma S1P levels compared with the AA and AG genotypes in ARDS patients. The serum S1P levels of rs 907045 AA or TA genotype patients were lower than that of TT genotype patients. Thus, it is more likely that $\mathrm{A}$ to $\mathrm{G}$ variation of rs3743631 and $\mathrm{T}$ to A variation of rs 907045 in S1P gene increase the onset of ARDS.

Our study also has limitations. First, the smaller sa ie size of patients may limit power to investigat the ass ciation between functional SNPs and S1P vel. All the subjects were from Chinese Han popu'ation. It is ossible that ethnic and genetic differences nay alsc influence the association between S1P polymor ism nd serum S1P levels. Second, apoM was ntly iaentified as the responsible binding protein of 51 t the blood [32]. We were not able to obt infor ation on apoM levels owing to limitations ir. ur ata. T/ird, because patients with trauma, drug overus and other less common risk

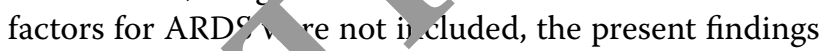
may not be sneralı 'le. Considering the heterogeneity and var ous nanifes ations of ARDS, the study results should be minf $d$ in larger samples to evaluate our

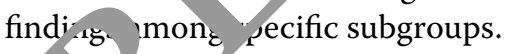

\section{Conclu ons}

Serum S1P levels are decreased in ARDS patients. Low serum S1P levels are associated with multiple organ dysfunction and adverse clinical outcomes in ARDS patients. Analysis of S1P gene polymorphism revealed that A to G variation of rs3743631 and $\mathrm{T}$ to A variation of rs 907045 in S1P gene increased the risk of ARDS, as validated by actual measurements of serum S1P levels. A potential therapeutic strategy that would involve increasing the serum S1P levels during illness may be desirable. Further studies with larger populations are needed before our findings can be generalized to all ARDS patients.

\section{Abbreviations}

ARDS: Acute respiratory distress syndrome; S1P: Sphingosine-1-phosphate SNPs: Single nucleotide polymorphisms; S1PR: Sphingosine-1-phosphate receptor; ALI: Acute lung injury; ICU: Intensive care unit; EMR: Electrnnic medical record; VFDs: Ventilator-free days; WBC: White blood cell; APAC, AE II: Acute Physiology and Chronic Health Evaluation II; ELISA: Enzyme lip 4 imr nnesorbent assays; MAF: Minimum allele frequency; UTR: Untranslato ggion; iMLDR: Improved Multiple Ligase Detection Reaction; AlJC: Areas un $r+$ ine curves; ROC: Receiver operating characteristic; OR: Q ratios; $\mathrm{Cl}$ Cor ndence interval; n.s: Non-significant; IQR: Interquartile ran "e; PF: $\mathrm{D}_{2} / \mathrm{FiO}$.

\section{Acknowledgements}

This study was supported by the Nation $\mathrm{Na}$ al Sciens? Foundation of China (81470206) and National Nata Scier china (81670073). We thank Binchan He ija Ji nd Yu Gu for collaboration in the survey.

\section{Authors' contributions}

$J Z$ and YS take respon iNm for the ace aracy of the data analysis and drafting the manuscript. YT and $\mathrm{KS}$ were responsible for study design and revision of the manuscript. All a ors cum and approved the final manuscript.

\section{Funding}

National Natu al foundation of China (81470206) and National Natural Science Found cion or China (81670073)

\section{AVa. ility of uata and materials}

All data enerated or analyzed during this study are included in this published ticle

\section{Ett . cs approval and consent to participate}

nformed consent was obtained from patients' legal representatives. The protocol was approved by the ethics committee of Jinling Hospital and Nanjing First Hospital (Approval Number: JLYY: 2013021).

\section{Consent for publication}

Not applicable.

\section{Competing interests}

The authors declare that they have no competing interests.

\section{Author details}

${ }^{1}$ Department of Respiratory and Critical Medicine, Jinling Hospital, Medical School of Nanjing University, No. 305 Zhongshan East Road, Nanjing 210000, China. ${ }^{2}$ Department of Respiratory Medicine, Nanjing First Hospital, Nanjing Medical University, Nanjing 210000, China.

Received: 9 January 2020 Accepted: 28 March 2020

Published online: 06 April 2020

\section{References}

1. Force ADT, Ranieri VM, Rubenfeld GD, Thompson BT, Ferguson ND, Caldwell E, Fan E, Camporota L, Slutsky AS. Acute respiratory distress syndrome: the Berlin Definition. JAMA. 2012;307(23):2526-33.

2. Ashbaugh DG, Bigelow DB, Petty TL, Levine BE. Acute respiratory distress in adults. Lancet. 1967;2(7511):319-23.

3. Suresh R, Kupfer $Y$, Tessler S. Acute respiratory distress syndrome. N Engl J Med. 2000;343(9):660-1.

4. Matthay MA, Zemans RL. The acute respiratory distress syndrome: pathogenesis and treatment. Annu Rev Pathol-Mech. 2011;6:147-63.

5. Swan DJ, Kirby JA, Ali S. Vascular biology: the role of sphingosine 1-phosphate in both the resting state and inflammation. J Cell Mol Med. 2010;14(9):2211-22.

6. Marsolais D, Rosen H. Chemical modulators of sphingosine-1-phosphate receptors as barrier-oriented therapeutic molecules. Nat Rev Drug Discov. 2009;8(4):297-307.

7. Sammani S, Moreno-Vinasco L, Mirzapoiazova T, Singleton PA, Chiang ET, Evenoski CL, Wang T, Mathew B, Husain A, Moitra J, et al. Differential effects of sphingosine 1-phosphate receptors on airway and 
vascular barrier function in the murine lung. Am J Respir Cell Mol Biol. 2010;43(4):394-402.

8. English D, Welch Z, Kovala AT, Harvey K, Volpert OV, Brindley DN, Garcia JG. Sphingosine 1-phosphate released from platelets during clotting accounts for the potent endothelial cell chemotactic activity of blood serum and provides a novel link between hemostasis and angiogenesis. FASEB J. 2000;14(14):2255-65.

9. Liu F, Verin AD, Wang P, Day R, Wersto RP, Chrest FJ, English DK, Garcia JG Differential regulation of sphingosine-1-phosphate- and VEGF-induced endothelial cell chemotaxis. Involvement of G(ialpha2)-linked Rho kinase activity. Am J Resp Cell Mol Biol. 2001;24(6):711-9.

10. Winkler MS, Nierhaus A, Holzmann M, Mudersbach E, Bauer A, Robbe L, Zahrte C, Geffken M, Peine S, Schwedhelm E, et al. Decreased serum concentrations of sphingosine-1-phosphate in sepsis. Crit Care. 2015;19:372.

11. Gomes L, Fernando S, Fernando RH, Wickramasinghe N, Shyamali NL, Ogg GS, Malavige GN. Sphingosine 1-phosphate in acute dengue infection. PLoS ONE. 2014;9(11):e113394.

12. McVerry BJ, Peng X, Hassoun PM, Sammani S, Simon BA, Garcia JG. Sphingosine 1-phosphate reduces vascular leak in murine and canine models of acute lung injury. Am J Respir Crit Care Med. 2004;170(9):987-93.

13. Darwish I, Liles WC. Emerging therapeutic strategies to prevent infectionrelated microvascular endothelial activation and dysfunction. Virulence. 2013;4(6):572-82.

14. Teijaro JR, Walsh KB, Cahalan S, Fremgen DM, Roberts E, Scott F, Martinborough E, Peach R, Oldstone MB, Rosen H. Endothelial cells are central orchestrators of cytokine amplification during influenza virus infection. Cell. 2011;146(6):980-91.

15. Sun XG, Ma SF, Wade MS, Acosta-Herrera M, Villar J, Pino-Yanes M, Zhou T, Liu B, Belvitch P, Moitra J, et al. Functional promoter variants sphingosine 1-phosphate receptor 3 associate with susceptibility sepsis-associated acute respiratory distress syndrome. Am J Phvsio C. 2013;305(7):L467-77.

16. LeGall JR, Loirat P, Alperovitch A. APACHE II-a severity of als classificc tion system. Crit Care Med. 1986;14(8):754-5.

17. Knaus WA, Draper EA, Wagner DP, Zimmerman JE AINHE Il: a se tity of disease classification system. Crit Care Med. 198 ;13(10):818-29.

18. Hanel P, Andreani P, Graler MH. Erythrocytes sto and relea es sphingosine 1-phosphate in blood. FASEB J. 2007;21(4):1 9.

19. Schaphorst KL, Chiang E, Jacobs KN, Zc $\mathrm{A}$, Natarajan V, Wigley F, Garcia JG. Role of sphingosine-1 phospl ate w nonancement of endothelial barrier integrity by platelet-re ased oducts. Am J Physiol Lung Cell Mol Physiol. 2003;

20. Venkataraman K, Lee YM, hauc I Thand da S, Ai Y, Bonkovsky HL,

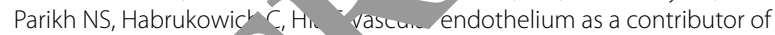
plasma sphingosine -phospha circ Res. 2008;102(6):669-76.

21. Christoffersen $C J b_{1}, \exists H, K u m a$ aswamy SB, Galvani S, Ahnstrom J, Sevvana M, En re -Siebu Muller YA, Hla T, Nielsen LB, et al. Endothelium-prote ave sphingosit 1-phosphate provided by HDL-associated apolipe - tein .... Prec Natl Acad Sci USA. 2011;108(23):9613-8.

22. Murata N, S. K, Kor s, Tomura H, Yanagita M, Kuwabara A, Ui M, Okajima

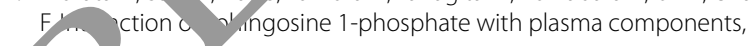

including lipoproteins, regulates the lipid receptor-mediated actions. Biochem J. 2000;352:809-15.

23. Garcia JG, Liu F, Verin AD, Birukova A, Dechert MA, Gerthoffer WT, Bamberg JR, English D. Sphingosine 1-phosphate promotes end . Alial cell barrier integrity by Edg-dependent cytoskeletal rearrange nent." 'Clin Invest. 2001;108(5):689-701.

24. Proia RL, Hla T. Emerging biology of sphingosine-1-phosphate $\mathrm{rol}^{\mathrm{l}}$ - in pathogenesis and therapy. J Clin Invest. 2015;125 1):1379-87.

25. Peng X, Hassoun PM, Sammani S, McVerry B」 Burn MJ, Rabl 'H, Pearse D, Tuder RM, Garcia JG. Protective effects osp. ingos. 1-r, nosphate in murine endotoxin-induced inflamma ory lung injury, $\mathrm{Im} J$ Respir Crit Care Med. 2004;169(11):1245-51.

26. Camerer E, Regard JB, Cornelissen Sriniv $n$ Y. D ong DN, Palmer D, Pham TH, Wong JS, Pappu R, Cougr SR. Sprmigosine-1-phosphate in the plasma compartment r gulates ba and inflammation-induced vascular leak in mice. J Cin est. 2009;1 9(7):1871-9.

27. Kawa S, Kimura S, Hako, ori S, rashi Y. Inhibition of chemotactic motility and trans-endo migratio of human neutrophils by sphingosine 1-phosphate. Fr BS Le 1997;420(2-3):196-200.

28. Sammani S, Parn Mlathew B, Wang T, Huang Y, Zhou T, Lussier YA, Husain AN, Mo -Vinasco L, et al. A sphingosine 1-phosphate 1 recept onist moa ates brain death-induced neurogenic pulmonary injury. A n s, coll Mol. 2011;45(5):1022-7.

29. Teijaro JA Walsh _B, Long JP, Tordoff KP, Stark GV, Eisfeld AJ, Kawaoka $Y$, Rosen A Oldstone MBA. Protection of ferrets from pulmonary injury ve to H1 2009 influenza virus infection: immunopathology tractable phingosine-1-phosphate 1 receptor agonist therapy. Virology. 20 4;452:152-7.

oreno-Vinasco L, Bonde P, Jacobson J, Garcia JGN. Attenuation of rodent lung ischemia/reperfusion injury by sphingosine 1-phosphate. J Invest Med. 2005:53(2):S366-S366.

31. Walsh KB, Teijaro JR, Wilker PR, Jatzek A, Fremgen DM, Das SC, Watanabe T, Hatta M, Shinya K, Suresh M, et al. Suppression of cytokine storm with a sphingosine analog provides protection against pathogenic influenza virus. Proc Natl Acad Sci USA. 2011;108(29):12018-23.

32. Christoffersen C, Benn M, Christensen PM, Gordts PLSM, Roebroek AJM, Frikke-Schmidt R, Tybjaerg-Hansen A, Dahlback B, Nielsen LB. The plasma concentration of $\mathrm{HDL}$-associated apoM is influenced by LDL receptor-mediated clearance of apoB-containing particles. J Lipid Res. 2012;53(10):2198-204.

\section{Publisher's Note}

Springer Nature remains neutral with regard to jurisdictional claims in published maps and institutional affiliations.

Ready to submit your research? Choose BMC and benefit from:

- fast, convenient online submission

- thorough peer review by experienced researchers in your field

- rapid publication on acceptance

- support for research data, including large and complex data types

- gold Open Access which fosters wider collaboration and increased citations

- maximum visibility for your research: over $100 \mathrm{M}$ website views per year

At BMC, research is always in progress.

Learn more biomedcentral.com/submissions 